\title{
Pulmonary function, white blood corpuscles \& haemoglobin levels in asymptomatic light smokers and non-smokers
}

\author{
Sharath $\mathbf{R}^{1}$, Pavithran $\mathbf{P}^{2}$, Das $\mathrm{SK}^{3}$ \\ ${ }^{1}$ Dr. Sharath Rao, Postgraduate in Physiology, ${ }^{2}$ Dr. Purushothaman Pavithran, Assistant Professor of Physiology, \\ ${ }^{3}$ Dr. Shirahatti Krishna Das, Professor \& Head of Physiology; all authors are attached with Department of Physiology, \\ A.J. Institute of Medical Sciences and Research Centre, Kuntikana, Mangalore, Karnataka, India.
}

Address of Correspondence: Dr. Pavithran P, Assistant Professor of Physiology, A.J. Institute of Medical Sciences and Research Centre, Mangalore, Karnataka, India. Email: drpavithran@ajims.edu.in

\begin{abstract}
Context: Smoking, a risk factor for several diseases has also been reported as the largest preventable cause of morbidity and mortality globally. Tobacco smoking is associated with a decrease in lung function in smokers when compared to non-smokers. Aims: To study and compare pulmonary function, WBC count and Hb levels in asymptomatic light smokers and non-smokers. Settings and Design: Case control study. Methods and Material: Patient relatives or subjects who had come for health check with a known history of smoking and apparently asymptomatic were recruited as our study subjects $(\mathrm{n}=49)$. Healthy volunteers were also recruited from patient relatives. Subjects without any known history of smoking were selected as controls $(n=50)$. Statistical analysis used: Data was analysed using SPSS V-19. P value $\leq 0.05$ was considered significant. Results: A statistically significant difference was found in total leucocyte count in smokers $(\mathrm{P}=0.004)$ when compared to non-smokers. There was also a statistically significant increase in absolute neutrophil $(\mathrm{P}=0.021)$, monocyte $(\mathrm{P}=0.004)$ and eosinophil $(\mathrm{P}=0.075)$ counts in smokers. FEV1/FVC $(\mathrm{P}=0.005)$ and FEF $75(\mathrm{P}=0.027)$ was significantly higher in non-smokers when compared to smokers. No significant difference was observed in haemoglobin concentration and differential leucocyte count, pulse rate, systolic pressure, diastolic pressure and rate pressure product among the two groups. Conclusions: The present study gives ample evidence for the damage to the respiratory system along with activation of immune system as evident from a significant lowering of small airway patency and increased white cell counts.
\end{abstract}

Key-words: Pulmonary function, White blood corpuscles, Smokers, Non-smokers,

\section{Introduction}

Smoking, a risk factor for several diseases has also been reported as the largest preventable cause of mortality globally [1-3]. In a study on Industrial population in India, $40.2 \%$ of men and $14.9 \%$ of women has been reported to have the habit of using tobacco.

The authors have also reported smoking to be the major form of tobacco consumption [4]. Among tobacco users in Mumbai, cigarette smokers have been reported to have a relative risk of mortality of 1.39 [5]. Tobacco smoking has been reported to have caused 700,000 deaths in India in the year 2000 alone [6].

Manuscript received: $11^{\text {th }}$ December 2016

Reviewed: $20^{\text {th }}$ December 2016

Author Corrected: $26^{\text {th }}$ December 2016

Accepted for Publication: $3^{\text {rd }}$ January 2017
A decrease in pulmonary function is smokers have been well established. Studies have reported forced expiratory volume in $1 \mathrm{sec}$ (FEV1) to be lowest in cigarette smokers [7]. A lower and a rapid decline in lung function in smokers when compared to age and height matched non-smokers has also been reported [8]. A longitudinal study on Norwegian men for seven years has reported a lower FEV1 in smokers as compared to non-smokers [9].

Studies from India have also shown the ill effects of smoking on lung function parameters. A study from rural Maharashtra has reported a decrease in all pulmonary function parameters in smokers [10]. Studies have also reported a decrease in FEV1, force vital 
capacity (FVC), FEV1/FVC in smokers [11, 12]. Haematological parameters have also been reported to be altered in smokers. An increase in total leucocyte count [13], an increase in neutrophils and eosinophils in smokers has been reported previously [14]. A dose response relation between smoking and white cell counts has also been reported [15]. High white blood cell (WBC) count has been reported to be a strong and independent predictor of coronary risk in patients of both sexes [16].

Most of these reported studies have been carried out on moderate and heavy smokers. The purpose of the planned study was to evaluate lung function, $\mathrm{Hb}$ and easily attainable markers of inflammation such as WBC count in light smokers and their by assess the cardiovascular risk associated with these apparently healthy individuals. Not many studies have reported cardiovascular risk associated with light smoking.

\section{Subjects and Methods}

The present study was carried out in the department of Physiology and Medicine outpatient department. Patient relatives with a known history of smoking and apparently asymptomatic were recruited as our study subjects $(n=49)$. Healthy volunteers were also recruited from patient relatives. Subjects without a known history of smoking were selected $(n=50)$. Subjects with a history of recent drug therapy, any disease affecting blood counts and pulmonary function was excluded from the study. The classification of study subjects as light smokers was based on pack years [17]. All the subjects included in the present study are males.
Written informed consent was collected from all the study participants. Institute Ethical committee clearance was also obtained. Necessary care was taken to comply with the World Medical Association Declaration of Helsinki regarding ethical conduct of research involving human subjects. A day prior to actual recording $5 \mathrm{ml}$ of venous blood was collected for the estimation of $\mathrm{Hb}$ concentration, total leucocyte count (TLC) and differential leucocyte count (DLC). Absolute values for each type of cell was then calculated (Cotter S Hematology). Blood parameters were analysed using Sysmex XN-1000 ${ }^{\mathrm{TM}}$ Hematology Analyzer (Sysmex America). On the day of recording, blood pressure was recorded using a mercury sphygmomanometer as per the recommendations of the JNC 7 guidelines [18].

Height and weight were measured and BMI was calculated as weight in $\mathrm{kg}$ divided by the square of the height in units of meter squared. Lung function parameters were assessed using RMS Helios 401(RMS, India) Spirometer connected to a Windows based computer. The parameters recorded were FEV1, FVC, FEV1/FVC, FEF25-75, FEF 25\%, FEF 50\% and FEF $75 \%$. The recordings were based on the American thoracic society and European respiratory society task force report [19].

Statistical Analysis- Data are presented as the means \pm SD unless mentioned otherwise. IBM SPSS statistics (Version 22.0. Armonk, NY: IBM Corp) software for Windows was used in data analysis. Unpaired test or Mann Whitney $\mathrm{U}$ test was used as appropriately for the comparison of the two groups. A 2-tailed $\mathrm{P}$ value $\leq 0.05$ was considered statistically significant.

\section{Results}

No statistically significant difference was observed in age, height, weight and body mass index between smokers and non-smokers' [Table 1]. No significant difference was also observed in haemoglobin ( $\mathrm{Hb}$ ) concentration and differential leucocyte count (DLC) among the two groups as shown in table 2. There was a statistically significant difference in TLC in smokers $(\mathrm{P}=0.004)$ as compared to non-smokers although the increase was within the normal limits.

Table-1: Age \& anthropometric parameters between smokers and non-smokers. Data expressed as mean \pm SD.

\begin{tabular}{|c|c|c|c|}
\hline & Smokers (50) & Non-smokers (50) & P value \\
\hline Age (yrs) & $29.98 \pm 7.779$ & $32.28 \pm 6.809$ & 0.119 \\
\hline Height $(\mathrm{mts})$ & $1.685 \pm 0.074$ & $1.683 \pm 0.069$ & 0.878 \\
\hline Weight $(\mathrm{Kg})$ & $66.940 \pm 8.524$ & $66.920 \pm 11.900$ & 0.992 \\
\hline BMI & $23.494 \pm 1.898$ & $23.545 \pm 3.414$ & 0.928 \\
\hline Height $(\mathrm{mts})$ & $1.685 \pm 0.074$ & $1.683 \pm 0.069$ & 0.878 \\
\hline
\end{tabular}


BMI: Body Mass Index

Table-2: Haemoglobin concentration, Total and differential leucocytes count in smokers and non-smokers. Date expressed as mean \pm SD.

\begin{tabular}{|c|c|c|c|}
\hline & Smokers (50) & Non-smokers (50) & P value \\
\hline Haemoglobin $(\mathrm{g} \%)$ & $14.250 \pm 1.375$ & $14.380 \pm 1.325$ & 0.632 \\
\hline WBC count $\left(\right.$ cells $\left./ \mathrm{mm}^{3}\right)$ & $7744.00 \pm 1813.122$ & $6754.00 \pm 1521.439$ & 0.004 \\
\hline
\end{tabular}

WBC: white blood corpuscles.

Table 3 shows the absolute leucocyte count in smokers and non-smokers. There was a statistically significant increase in neutrophil $(\mathrm{P}=0.021)$, monocyte $(\mathrm{P}=0.004)$ and eosinophil $(\mathrm{P}=0.075)$ count in smokers as compared to non-smokers. No statistically significant different was observed in pulse rate, systolic pressure, diastolic pressure and rate pressure product [Table 4].

Table-3: Absolute leucocyte count in smokers and non-smokers. Data expressed as mean \pm SE.

\begin{tabular}{|c|c|c|c|c|c|}
\hline & Smokers (50) & $\mathbf{9 5 \%}$ CI & Non-smokers (50) & 95\% CI & $\boldsymbol{P}$ value \\
\hline Neutrophils & $4093 \pm 175$ & $3756-4452$ & $3570 \pm 138$ & $3300-3850$ & 0.021 \\
\hline Lymphocytes & $2485 \pm 110$ & $2270-2701$ & $2341 \pm 97$ & $2165-2532$ & 0.38 \\
\hline Monocytes & $627 \pm 26$ & $578-672$ & $524 \pm 24$ & $475-569$ & 0.004 \\
\hline Eosinophils & $400 \pm 43$ & $312-486$ & $304 \pm 31$ & $242-377$ & 0.075 \\
\hline Basophils & $43 \pm 7$ & $39-57$ & $40 \pm 6$ & $28-53$ & 0.767 \\
\hline
\end{tabular}

95\% CI: $95 \%$ confidence interval

Table-4: Cardiovascular parameters in smokers and non-smokers. Data expressed as mean \pm SD.

\begin{tabular}{|c|c|c|c|}
\hline & Smokers (50) & Non-smokers (50) & P value \\
\hline Pulse rate (BPM) & $72.56 \pm 6.020$ & $73.48 \pm 8.664$ & 0.539 \\
\hline Systolic BP (mmHg) & $120.20 \pm 7.910$ & $119.40 \pm 9.598$ & 0.650 \\
\hline Diastolic BP (mmHg) & $77.68 \pm 6.967$ & $77.84 \pm 8.683$ & 0.919 \\
\hline Rate Pressure Product & $87.13 \pm 8.200$ & $88.05 \pm 15.142$ & 0.705 \\
\hline
\end{tabular}

Bpm: beats per minute

Table-5: Spirometric parameters in smokers and non-smokers. Data expressed as mean \pm SD.

\begin{tabular}{|c|c|c|c|}
\hline & Smokers (50) & Non-smokers (50) & P value \\
\hline FEV1 (lts) & $2.86 \pm 0.776$ & $2.84 \pm 0.618$ & 0.844 \\
\hline FVC (lts) & $3.30 \pm 0.715$ & $3.14 \pm 0.585$ & 0.309 \\
\hline FEV1/FVC (\%) & $86.80 \pm 16.051$ & $91.04 \pm 15.827$ & 0.005 \\
\hline FEF25-75 (lts) & $3.70 \pm 1.284$ & $4.05 \pm 1.180$ & 0.203 \\
\hline FEF 25 (lts) & $5.83 \pm 2.607$ & $5.91 \pm 2.147$ & 0.684 \\
\hline FEF50 (lts) & $4.25 \pm 1.612$ & $4.50 \pm 1.411$ & 0.393 \\
\hline FEF 75 (lts) & $2.12 \pm 0.792$ & $2.53 \pm 0.899$ & 0.027 \\
\hline
\end{tabular}

FEV1: Forced expiratory volume at one second, FVC: Forced vital capacity, FEF: Forced expiratory flow. 
Table-6: Percentage predicted spirometric parameters in smokers and non-smokers. Data expressed as mean \pm SD

\begin{tabular}{|c|c|c|c|}
\hline & Smokers (50) & Non-smokers (50) & P value \\
\hline Percentage predicted FEV1 & $86.22 \pm 18.142$ & $95.20 \pm 17.985$ & 0.001 \\
\hline Percentage predicted FVC & $84.28 \pm 10.435$ & $88.60 \pm 13.548$ & 0.076 \\
\hline Percentage predicted FEV1/FVC & $103.84 \pm 18.668$ & $108.46 \pm 18.590$ & 0.008 \\
\hline Percentage predicted FEF 25-75 & $82.00 \pm 24.669$ & $94.12 \pm 24.249$ & 0.029 \\
\hline Percentage predicted FEF 25 & $73.16 \pm 32.985$ & $74.42 \pm 27.740$ & 0.754 \\
\hline Percentage predicted FEF 50 & $76.84 \pm 31.236$ & $78.56 \pm 25.630$ & 0.672 \\
\hline Percentage predicted FEF 75 & $75.68 \pm 24.672$ & $85.80 \pm 25.261$ & 0.072 \\
\hline
\end{tabular}

FEV1: Force expiratory volume in 1 second; FVC: Forced vital capacity; FEF 25-75: forced mid expiratory flow $25-75 \%$.

Table 5 shows the lung function parameters in two groups. FEV1/FVC $(\mathrm{P}=0.005)$ and FEF $75(\mathrm{P}=0.027)$ was significantly higher in non-smokers when compared to smokers. None of the other pulmonary function parameters in absolute values were significantly different between the two groups. Percentage predicted values of FEV1 $(\mathrm{P}=0.001)$, FEV1/FVC $(\mathrm{P}=0.008)$ and FEF 25-75 $(\mathrm{P}=0.029)$ were significantly higher in non-smokers as compared to smokers (Table 6).

\section{Discussion}

The present study was planned to evaluate the effect of smoking on lung function test, haemoglobin and white blood count in asymptomatic light smokers. Although no significant difference in $\mathrm{Hb}$ and DLC was observed, there was a statistically significant difference in TLC, absolute neutrophil, monocyte and eosinophil count, with the count being higher in smokers.

In contrast to our findings are studies which have reported an increase in $\mathrm{Hb}$ levels in smokers as compared to non-smokers $[20,12]$. The authors have attributed this to hypoxic stimulation of $\mathrm{Hb}$ production in smokers owing to carbon monoxide present in cigarette smoke. Various other studies have reported an increase in leucocyte count, which are in line with the findings of the present study [22, 23]. TLC and leucocyte subsets as estimated by DLC have also been reported to be higher in smokers [24].

Most of these studies have employed DLC and the study subjects were mild to moderate smokers. An increase in WBC count in light smokers has also been reported previously [25]. Moreover, in the present study we have reported significance levels in WBC subsets based on absolute counts.

The presence of elevated WBC subsets gives a picture of allergic reaction.
Elevated markers of allergy have been previously reported in smokers. Along with an increase in TLC, the study also reported an increase in eosinophils and serum IgE levels [26]. This increase in WBC count has been considered to be an acute effect of smoking [14].

The probable reason for only a mild increase in WBC count in our study group could be due to the fact that our smokers were mostly light smokers. The same fact has also been highlighted by the reported dose response relationship between smoking and WBC counts [14, 24]. The increase in WBC count in smokers has also been attributed to activation of the inflammatory system [22], endothelial damage [21, 27] and also via increase in catecholamine release by nicotine present in cigarettes [14].

WBC counts have emerged as a marker of inflammation that is widely available in clinical practice [28]. Inflammation plays an important role in the development of cardiovascular disease. An elevated WBC counts in our study subset probably highlights the risk associated with these group of light smokers who were otherwise healthy.

No significant change in $\mathrm{BP}$, pulse rate and RPP was observed in smokers when compared to non-smokers. Contrasting reports have been documented from various 
studies on the effect of smoking on BP and heart rate (HR). Heavy smoking has been found to be associated with persistent elevation in BP and increase in blood pressure variability [29]. Increase in BP and HR has also been reported in habitual smokers.

The authors have attributed these changes to the arterial wall stiffening effect brought about by nicotine [30].

FEV1/FVC ratio is the corner stone for the diagnosis of obstructive airway disease [31]. In the present study we did not find smokers falling into this disease category in spite of the fact that FEV1/FVC was significantly lower in smokers compared to non-smokers.

The percentage of predicted values of FEV1 and FEV1/FVC were also significantly lower in smokers. FEF25-75\% is the average expired flow over the middle half of the FVC manoeuvre and is regarded as a more sensitive measure of small airways narrowing.

The predicted value for FEF $25-75 \%$ were also was significantly lower in smokers. The lower value for these parameters in our study of light smokers is probably an indication of increasing smaller airway obstruction in these people as compared to nonsmokers.

Cigarette smoking has been well documented to have deleterious effect on the respiratory system. Injury to the lung is attributed to the harmful chemicals present in cigarette smoke [32].

A progressive decrease in expiratory flow rates with increasing cigarette usage has also been reported previously [33]. A lower FEV1, FVC, FEV1/FVC\% and $\mathrm{FEV} 1 \%$ predicted has also been reported in smokers [34, 35]. In contrast to our finding are the observations of no significant difference of FEV1/FVC in smokers and non-smokers [12].

Damage to the respiratory system even in the case of light smokers is clearly apparent from the present study. Mild changes if not properly taken care of will surely result in severe cases of obstructive disease.

In view of the rising incidents of death owing to tobacco smoking our results finds significance.

Funding: Nil, Conflict of interest: None. Permission of IRB: Yes

\section{References}

1. Ezzati M, Lopez AD. Estimates of global mortality attributable to smoking in 2000. Lancet. 2003 Sep 13; 362 (9387):847-52.

2. Lal PG, Wilson NC, Gupta PC. Attributable deaths from smoking in the last 100 years in India. Curr Sci [Internet]. 2012; Available from: http://www. indiaenvironmentportal.org. in/files/file/deaths\% 20 from $\%$ 20smoking.pdf.

3. Zheng W, McLerran DF, Rolland BA, et al. Burden of total and cause-specific mortality related to tobacco smoking among adults aged $\geq 45$ years in Asia: a pooled analysis of 21 cohorts. PLoS Med. 2014 Apr 22;11(4):e1001631. doi: 10.1371/journal. pmed. 1001631. eCollection 2014.

4. Reddy KS, Prabhakaran D, Chaturvedi V, Jeemon P, Thankappan KR, Ramakrishnan L, et al. Methods for establishing a surveillance system for cardiovascular diseases in Indian industrial populations. Bull World Health Organ [Internet]. 2006 Jun;84(6):461-9. Available from: http://dx.doi.org//S0042-9686200 6000600015 .

5. Gupta PC, Mehta HC. Cohort study of all-cause mortality among tobacco users in Mumbai, India. Bull World Health Organ. 2000;78(7):877-83.

6. Gajalakshmi V, Peto R, Kanaka TS, Jha P. Smoking and mortality from tuberculosis and other diseases in India: retrospective study of 43000 adult male deaths and 35000 controls. Lancet. 2003 Aug 16;362 (9383):507-15.

7. Comstock GW, Brownlow WJ, Stone RW, Sartwell PE. Cigarette smoking and changes in respiratory findings. Am J Epidemiol. 2008 Oct 1;168(7):802-9. doi: 10.1093/aje/kwn321.

8. Peat JK, Woolcock AJ, Cullen K. Decline of lung function and development of chronic airflow limitation: a longitudinal study of non-smokers and smokers in Busselton, Western Australia. Thorax 1990 Jan; 45(1):32-7.

9. Sandvik L, Erikssen G, Thaulow E. Long term effects of smoking on physical fitness and lung function: a 
longitudinal study of 1393 middle aged Norwegian men for seven years. BMJ. 1995 Sep 16;311(7007):715-8.

10. Ahmad N, Bano R, Mattoo F, Mattoo GM. A comparative Study of Lung Function Tests in Smokers and Non-smokers in Rural Maharashtra. J Med Sci. 2009;12(2).

11. Kumar J, Kumar G, Sharma AK, Khan FA, Sharma SJ. The Effect of Smoking on the Blood Parameters of Young Adults. Journal of Clinical and Diagnostic Research [Internet]. 2012; 6 (7): 1244-7.

12. Vyas HP, Vinchhi RP, Sheth MS, Vyas NJ. Comparison of pulmonary function among smokers and non-smokers - A retrospective study. Int J Med Sci Public Health 2014;3 (Online First). DOI: 10.5455/ ijmsph.2014.090720144.

13. Parry H, Cohen S, Schlarb JE, Tyrrell DA, Fisher A, Russell MA, et al. Smoking, alcohol consumption, and leukocyte counts. Am J Clin Pathol. 1997 Jan;107 (1):64-7.

14. Sunyer J, Muñoz A, Peng Y, Margolick J, Chmiel $\mathrm{JS}$, Oishi $\mathrm{J}$, et al. Longitudinal relation between smoking and white blood cells. Am J Epidemiol. 1996 Oct $15 ; 144(8): 734-41$.

15. Raj JB, Kumar S, Jennifer G. Association of High Peripheral Neutrophil Count in Healthy Young Smokers With Impaired Pulmonary Function Test. Sch J App Med Sci, 2013;1(4):245-8. Available from: http:// saspublisher. com/ wp-content/ uploads/2013/ 08/ SJAMS14245-248.pdf.

16. Gillum RF, Mussolino ME, Madans JH. Counts of neutrophils, lymphocytes, and monocytes, causespecific mortality and coronary heart disease: the NHANES-I epidemiologic follow-up study. Ann Epidemiol. 2005 Apr;15(4):266-71.

17. Lee Y-H, Shin M-H, Kweon S-S, Choi J-S, Rhee JA, Ahn H-R, et al. Cumulative smoking exposure, duration of smoking cessation, and peripheral arterial disease in middle-aged and older Korean men. BMC Public Health. 2011 Feb 11;11:94. Available from: http: //dx. doi. org /10. 1186/1471-245811-94.
18. Chobanian AV, Bakris GL, Black HR, Cushman WC, Green LA, Izzo JL Jr, et al. Seventh report of the Joint National Committee on Prevention, Detection, Evaluation, and Treatment of High Blood Pressure. Hypertension 2003 Dec;42(6):1206-52.Available from: http: //dx. doi. org/10.1161/01. HYP. 0000107251. 49515.c2.

19. Miller MR, Hankinson J, Brusasco V, Burgos F, Casaburi R, Coates A, Crapo R, Enright P, van der Grinten CP, Gustafsson P, Jensen R, Johnson DC, MacIntyre N, McKay R, Navajas D, Pedersen OF, Pellegrino R, Viegi G, Wanger J; ATS/ERS Task Force. Standardisation of spirometry. Eur Respir J. 2005 Aug;26(2):319-38.

20. Goel A, Desh Deepak, Naveen Gaur. Study of relationship of tobacco smoking with haemoglobin concentration in healthy adults. Journal of Pharmacutical and Biomedical Sciences [Internet]. 2010;1(1):1-3.

21. Asif M, Karim S, Umar Z, Malik A, Ismail T, Chaudhary A, Alqahtani MH and Rasool M. Effect of cigarette smoking based on hematological. Türk Biyokimya Dergisi [Turkish Journal of BiochemistryTurk J Biochem] 2013;38(1):75-80. Available from: http://dx.doi.org/10.5505/tjb.2013.49369.

22. Yeung MC, Buncio AD. Leukocyte count, smoking, and lung function. Am J Med. 1984 Jan;76(1):31-7.

23. Tell GS, Grimm RH Jr, Vellar OD, Theodorsen L. The relationship of white cell count, platelet count, and hematocrit to cigarette smoking in adolescents: the Oslo Youth Study. Circulation. 1985 Nov;72(5):971-4.

24. Jensen JA, Goodson WH, Hopf HW, Hunt TK. Cigarette smoking decreases tissue oxygen. Arch Surg. 1991 Sep;126(9):1131-4.

25. Watanabe N, Fukushima M, Taniguchi A, Okumura T, Nomura Y, Nishimura F, et al. Smoking, white blood cell counts, and TNF system activity in Japanese male subjects with normal glucose tolerance. Tob Induc Dis . 2011 Nov 25;9(1):12. Available from: http://dx.doi. org/10.1186/1617-9625-9-12.

26. Taylor RG, Gross E, Joyce H, Holland F, Pride NB. Smoking, allergy, and the differential white blood cell count. Thorax. 1985 Jan;40(1):17-22. 
27. Taha NM, Abdel Wahab MA, Amin AS. Acute effects of cigarette smoking in habitual smokers, a focus on endothelial function. The Egyptian Heart Journal. 2014;65(4):275-9. Available from: http://dx. doi.org /10.1016/j.ehj.2012.09.003.

28. Madjid M, Fatemi O. Components of the complete blood count as risk predictors for coronary heart disease: in-depth review and update. Tex Heart Inst J. 2013;40(1):17-29.

29. Groppelli A, Giorgi DM, Omboni S, Parati G, Mancia G. Persistent blood pressure increase induced by heavy smoking. J Hypertens. 1992 May;10(5):495-9.

30. Kool MJ, Hoeks AP, Struijker Boudier HA, Reneman RS, Van Bortel LM. Short- and long-term effects of smoking on arterial wall properties in habitual smokers. J Am Coll Cardiol. 1993 Dec;22(7):1881-6.

31. Pellegrino R, Viegi G, Brusasco V, Crapo RO, Burgos F, Casaburi R, Coates A, van der Grinten CP, Gustafsson P, Hankinson J, Jensen R, Johnson DC, MacIntyre N, McKay R, Miller MR, Navajas D,
Pedersen OF, Wanger J. Interpretative strategies for lung function tests. Eur Respir J. 2005 Nov;26(5): 948-68.

32. Yanbaeva DG, Dentener MA, Creutzberg EC, Wesseling G, Wouters EFM. The Pathophysiology of Cigarette Smoking and Cardiovascular Disease. J Am Coll Cardiol 2007 May;131(10):1557-66. Available from: http://dx.doi.org/10.1378/chest.06-2179.

33. Kuperman AS, Riker JB. The variable effect of smoking on pulmonary function. Chest. 1973 May; 63(5):655-60.

34. Waseem S, Hossain MM, Islam N, Ahmad Z. Comparative study of pulmonary functions and oxidative stress in smokers and non-smokers. Indian $\mathbf{J}$ Physiol Pharmacol. 2012 Oct-Dec;56(4):345-52.

35. Khan A, Shabbir K, Ansari JK, Zia N. Comparison of forced expiratory volume in one second (FEV1) among asymptomatic smokers and non-smokers. J Pak Med Assoc [Internet]. 2010 Mar;60(3):209-13.

\section{How to cite this article?}

Sharath R, Pavithran P, Das SK. Pulmonary function, white blood corpuscles \& haemoglobin levels in asymptomatic light smokers and non-smokers. Int J Med Res Rev 2017;5(01):42-48. doi:10.17511/ijmrr. 2017.i01.06. 